\title{
“Hey, you! Job! Listen up." Elihu's Use of Job's Name and its Implications for Translation
}

\author{
STUART J. FOSTER (UNIVERSITY OF STELLENBOSCH) ${ }^{1}$
}

ABSTRACT

In the context of the book of Job and in light of patterns of biblical Hebrew usage, Elihu's uses of Job's name in direct address are strongly marked and reveal him as sharply disrespectful to Job. This should influence interpretation of the Elihu chapters and be reflected in Bible translations, taking into account cultural patterns for using names. Examples from northern Mozambique provide contrast to English, French, and Portuguese patterns.

KEYWORDS: Elihu, Book of Job, Names in direct address, Biblical Hebrew, Bible Translation

\section{A INTRODUCTION}

In his four monologues, Elihu uses Job's name nine times, addressing him directly $(33: 1,31,37: 14)$ and indirectly $(32: 12,34: 5,7,35,36 ; 35: 16)$. This is so striking that it demands explanation. It should influence interpretation of the notoriously complex role of Elihu and it should be reflected in translations.

This paper will first show how striking Elihu's usage is, within the book of Job, from the perspective of discourse linguistics, and in the light of patterns in Old Testament usage. It will then argue, in dialogue with an extensive range of commentaries, that the usage reveals him as rude and disrespectful to Job, encouraging the reader to have a critical attitude to Elihu and his comments. Lastly, it will make recommendations for translation, both in languages of northern Mozambique, where the author is based, and in modern European languages.

\section{B CALLING JOB BY HIS NAME}

Of course, Job's name is common in the book named after him. It is used thirty-seven times by the narrator, six times by YHWH and once by the Satan.

* Article submitted: 20/06/2016; peer reviewed: 6/07/2016; accepted: 6/07/2016. Stuart Foster, “'Hey, you! Job! Listen up.' Elihu's Use of Job's Name and its Implications for Translation," OTE 29 (3) 2016: 455-468. doi: http://dx.doi.org /10.17159/2312-3621/2016/v29n3a6

1 The author wishes to thank SIM Mozambique for allowing study time and Tyndale House, Cambridge, UK for critical resources and relationships. Tayeb and Cara Foster-Karim helped suggest the title. 
But in a book that is overwhelmingly direct speech, no-one, not even YHWH himself, uses it in speaking to Job, except Elihu. Elihu uses it over and over, even making direct demands for Job's attention by name both in his first speech (33:1) and in his last one (37:14). This is a key marker of Elihu's distinct style. Job's three friends never use his name at all. An explanation is called for.

From the perspective of discourse linguistics, Elihu's usage is highly marked. It is normal to introduce participants in a text and identify them again when there may be some ambiguity. But the redundant use of someone's name calls attention to itself. ${ }^{2}$ Runge puts the general principle this way: for "overencoded references to active participant that are found in contexts of high continuity - where there is clearly no transition in the discourse - the disruption in processing caused by the redundant encoding serves as something of a speed bump just before something surprising or important. It serves [a] pragmatic highlighting function to draw attention to what immediate[ly] follows." 3 Thus, "[i]f the form of address is not semantically required to identify the address[ee], one should move on to consider the other possible functions." ${ }^{4}$ In chapter 32 , Elihu addressed the three friends, presumably with Job listening in. From 33:1 on through chapter 37 , he addresses Job, presumably with the friends listening in. After 33:1, it is certainly not necessary to keep mentioning Job's name. The places where Job's name is mentioned are not transition points in the discourse. Rather, these instances represent "a marked usage," which can be used "to accomplish various thematic effects." It is those thematic effects that need to be determined from the context.

Elihu's usage of Job's name is also distinctive when compared to the rest of the Old Testament. I did an extensive, though not exhaustive survey of the use of personal names in direct address throughout the Old Testament (including Aramaic portions of Daniel). ${ }^{6}$ I identified ninety-seven instances, excluding Elihu's addresses to Job. This involved judgements from context in each case about whether or not direct address was involved. Disagreement about a particular case here or there should not change the overall pattern. I excluded references to a group of people ("O, Israel”), personifications

2 For background, see Steven E. Runge, "Pragmatic Effects of Semantically Redundant Anchoring Expressions in Biblical Hebrew Narrative," JNSL 32 (2006): 87-104.

3 Steven E. Runge, "Redundancy, Discontinuity and Delimitation in the Epistle of James." Paper presented in the "Hellenistic Greek Language and Literature" Section of the SBL International Meeting, July 3-7. (London: UK, 2011), 4.

4 Runge, "Redundancy," 14.

5 Runge, "Pragmatic," 88.

6 David Instone-Brewer of Tyndale House, Cambridge, UK provided invaluable assistance with compiling this list. It was not a straightforward search. 
("Bethlehem, Efrathah") and address to God in prayer (as a special case). ${ }^{7}$

(i) Most prominently, YHWH or God speaks to someone (eighteen times; Gen 15:1; 16:8; 17:5, twice; 22:1; 35:10; 46:2; Exod 3:4; 1 Sam 3:6, 10; 1 Kgs 19:9, 13; Jer 1:11; 24:3; Amos 7:8; 8:2; Hag 2:4, 23). ${ }^{8}$ Six more occasions could be added to these, when the Angel of YHWH speaks or a voice from heaven calls (Gen 21:17; 22:11; 32:28; Dan 4:28; 8:16; Zech 3:8).

(ii) On ten other occasions, God's authoritative representatives address someone by name. Prophets do this six times (Num 23:18; 2 Chr 15:2; Jer 20:3, 6; Dan 2:28, 5:22), angels four (Dan 9:22, 10:11, 12; 12:9).

(iii) Twenty-two times, kings speak to someone of lesser rank (Exod 5:4, 1 Sam 17:55; 22:16; 24:17; 26:17, 21, 25; 2 Sam 9:2, 6; 1 Kgs 22:15; 2 Kgs 9:22; 1 Chr 28:9; 2 Chr 18:14; Est 5:3; 7:2; Dan 3:14, 26; 4:6, 15, 16; 5:13; 6:21) and twice to a fellow king (2 Kgs 9:23; 2 Chr 13:4).

(iv) Fourteen times, Jacob/Israel addresses his sons in blessing (Gen 49:3, 5, $8,9,13,14,16,17,19,20,21,22,26,27){ }^{9}$ Also Melchizedek blesses Abram (Gen 14:19).

(v) Recognition is a theme in six cases: Isaac wonders if he is speaking to the right son (Gen 27:24). Fugitive David calls out to Abner in Saul's camp (1 Sam 26:14). ${ }^{10}$ The stunned woman of Endor recognises the king (1 Sam 28:12). Another woman confirms she is speaking to Abner (2 Sam 20:17). Abner calls out to the pursuing Asahel, also confirming recognition (2 Sam 2:20). Obadiah recognizes Elijah (1 Kgs 18:7).

(vi) Other usages are much less common. I count a total of eighteen. Twice, someone is addressed in a praise song (Judg 5:12; 1 Chr 12:19). ${ }^{11}$ Twice, there is a sharp rebuke, once by a prophet to another prophet (Jer 28:15), and once by a priest to a king (2 Chr 26:18). Hagar names God (Gen 16:13). In a crisis, Joshua calls out to Moses (Num 11:28). Moses commands and rebukes Korah

7 There are also five times that the addressee of a letter is named (Ezra 4:11, 17; $5: 7 ; 6: 6 ; 7: 12$ ). Strictly speaking, these are not direct addresses.

8 Four people even get a double use of their name: Abraham, Jacob, Moses and Samuel.

9 Moses's blessing of the tribes in Deut 33:2-29 is similar, though it is clear that not individuals are addressed by name. It could be argued that groups and not individuals are also in focus in Genesis 49.

10 David J. Clines sees in this instance that the use of a personal name demands an explanation. He argues that it is not to be seen here as a sign of disrespect: Cf. On the Way to the Postmodern: OTE, 1967-1998, 2 vols. (Sheffield: Sheffield Academic Press, 1998), 1: 248, n.12.

11 In three other instances, someone is addressed in a lament, but this cannot strictly be construed as direct address (2 Sam 1:23, 3:33, 19:4). 
(Num 16:6). A master challenges his servant (2 Kgs 5:25). An old man summons a small boy (1 Sam 3:16). A husband speaks to his wife (1 Sam 1:8) or his wives (Gen 4:23). Delilah wakes up Samson (Judg 16:12, 14, 20). Elijah urges Elisha (2 Kgs 2:4). Bathsheba prays a blessing on David (1 Kgs 1:31). Daniel's three friends defy Nebuchadnezzar, pointedly not even calling him king (Dan 3:16). ${ }^{12}$ Officials greet King Darius (Dan 6:7).

The latter less frequent examples can be analysed various ways. But they are rare; in each case, the use of a personal name in direct address calls for careful exegetical analysis. This should be standard practice. It is simply not common in Old Testament texts for an individual to be addressed by name. Yet Elihu uses Job's name nine times. No other individual in the entire Old Testament is called by his name that many times. And when a name is used in direct address, seventy-five times ( $77 \%$ of the time) a social superior speaks to an inferior (however, in the remaining twenty-two cases, this is not clear). Yet the junior Elihu uses Job's name nine times!

From the book of Job, from linguistics and from broad patterns in the Old Testament, many lines converge to show that Elihu's addressing Job by name demands serious attention.

\section{Was Elihu rude?}

This section will survey and evaluate proposals to account for Elihu's striking use of Job's name. It will then propose that seeing Elihu portrayed as rude and disrespectful, arrogating authority to himself, makes the best sense of the context.

\section{Overview of various scholars' views on Elihu's naming of Job}

It must be acknowledged that many commentators do not even mention the question. The demanding complexities of the book of Job can stimulate massive works of erudition. In many of them, Elihu's use of Job's name escapes explanation, or is not even noticed. Reyburn's 806 page handbook for Bible translators is one example. ${ }^{13}$ The commentaries of Ash, ${ }^{14}$ Cheney, ${ }^{15}$ Janzen, ${ }^{16}$ Longman, ${ }^{17}$ Terrien ${ }^{18}$ and Wharton ${ }^{19}$ are others.

\footnotetext{
12 In this Aramaic instance, it is ambiguous as to whether or not the king's name is part of the direct quote or not.

13 William D. Reyburn, A Handbook on the Book of Job (New York: United Bible Societies, 1992).

14 Christopher Ash, Job: The Wisdom of the Cross (Wheaton, Ill: Crossway, 2014).

15 Michael Cheney, Dust, Wind and Agony: Character, Speech and Genre in Job (Stockholm: Almqvist \& Wiksell, 1994).

16 J. Gerald Janzen, Job. Interpretation: A Bible Commentary for Teaching and Preaching (Atlanta: John Knox Press, 1985).

17 Tremper Longman III, Job (Grand Rapids: Baker Academic, 2012).
} 
Several other commentators note the question but dismiss it without much discussion. Rowley comments, "none of the other speakers had addressed Job by name, as Elihu does," 20 but leaves it there. Dhorme simply notes that Elihu, "has no hesitation in mentioning his [Job's] name." ${ }^{21}$ Clines, whose commentary is a monumental three volumes of painstaking work, concludes, "It is interesting, but perhaps of no special consequence, that the friends never mention Job's name but Elihu does so frequently.",22

Many see the Elihu chapters as a later addition to the book of Job (for example: Dhorme, ${ }^{23}$ Pope ${ }^{24}$ Rowley, ${ }^{25}$ and Terrien; ${ }^{26}$ on the other hand, Wilson, ${ }^{27}$ Habel $^{28}$ and Janzen ${ }^{29}$ disagree vigorously). It might therefore seem that the distinctive use of Job's name is merely a style difference pointing to different authorship. That conclusion, however, begs the question of what the style is attempting to communicate. It also ignores the evidence above from linguistics and the whole Old Testament corpus. This is a very unusual variation in style.

Other commentators briefly interpret the phenomenon. Nicole writes, "Cela donne à cette intervention un caractère à la fois intime et dramatique.",30 He does not say further how the intimate and dramatic character of what Elihu says, should affect its interpretation. Aquinas sees the use of Job's name in 33:1 as marking a change of addressee, ${ }^{31}$ but at that point makes no other observation. For Hakkam, Elihu shows that "he does not know how to speak

18 Samuel Terrien, Job, $2^{\text {nd }}$ ed. (Geneva: Labor et Fides, 2005).

19 James A. Wharton, Job, (Louisville, Ky: Westminster John Knox Press, 1999).

20 Harold H. Rowley, New Century Bible: Job (London: Marshall, Morgan \& Scott, 1976), 210.

21 Édouard Dhorme, A Commentary on the Book of Job, trans. Harold Knight, (London: Thomas Nelson, 1967), 486, cf. ci.

22 David J. Clines. Word Biblical Commentary, Volume 18A, Job 21-37 (Nashville: Tyndale House, 2006), 720.

23 Dhorme, Job, ci-cix.

24 Marvin R. Pope, The Anchor Bible: Job (Garden City, New York: Doubleday, 1973), xxvii.

25 Rowley, Job, 13, cf. 206.

26 Terrien, Job, 74.

27 Gerald H. Wilson, New International Biblical Commentary: Job (Peabody, Mass.: Hendrickson, 2007), 25.

28 Norman C. Habel, The Book of Job: A Commentary (London: SCM Press, 1985), 36.

29 Janzen, Job, 218.

30 Jules M. Nicole, Le Livre de Job, vol. 2 (Vaux sur Seine: Edifac, 1987), 150. "This gives to this comment a character at the same time both intimate and dramatic." 31 Thomas Aquinas, The Literal Exposition on Job: A Scriptural Commentary Concerning Providence, trans. Anthony Danico (Atlanta, Georgia: Scholars Press, 1989), 370. 
words of flattery." ${ }^{32}$ For Gordis, "Elihu is a younger man and an interloper to boot. He is worried as to whether he will gain and hold Job's attention and, therefore, addresses him by name." 33 Elihu was feeling insecure. ${ }^{34}$ Similarly, Pope says that the usage points to temperament: "This greater familiarity on the part of Elihu is scarcely to be attributed to closer ties of consanguinity between Job and Elihu than between Job and the three friends. It is in the nature of Elihu's temperament, or rather in that of the author of these speeches." ${ }^{35}$ All these observations may be accurate up to a point, but do not go far enough to account for the exaggerated intensity of Elihu's use of Job's name.

Habel, uniquely, incorporates Elihu's use of Job's name into his whole approach to understanding the Elihu chapters in the book. Indeed, "the Elihu speeches are best interpreted as an integral part of the structure of the book of Job" and Elihu's role is both "forensic and dramatic." ${ }^{36}$ Elihu's forensic role is that of "the self-designated 'adjudicator' of Job's case,"37 with Job's final oath at the end of chapter 31 a "key to the legal metaphor." 38 "The technique of addressing Job by name" court and legal language, ${ }^{40}$ appropriate to a formal address at a public hearing. ${ }^{41}$ This proposal takes the use of Job's name seriously and connects it to the issue of justice, a major theme in the whole book. It does not, however, account on its own for the frequency, the intensity, with which Elihu repeats Job's name.

Ash argues for accepting Elihu at face value as a prophet who grounds his authority in the Spirit of God and not in tradition. ${ }^{42}$ He suggests that, "the Lord simply picks up where Elihu left off, regarding Elihu as a positive and preparatory speaker." 43 This position, rare among contemporary commentators, is also held by Calvin ${ }^{44}$ and Lorik, ${ }^{45}$ and supported with qualification by

32 Amos Hakkam, The Bible: Job with the Jerusalem Commentary (Jerusalem: Mosad Harav Kook, 2009), 333.

33 Robert Gordis, The Book of Job: Commentary, New Translation and Special Studies (New York City: The Jewish Theological Seminary, 1978), 548.

34 Gordis, Job, 371.

35 Pope, Job, 247.

36 Habel, Job, 36.

37 Norman C. Habel, "The Role of Elihu in the Design of the Book of Job," in In the Shelter of Elyon: Essays of Ancient Palestinian Life and Literature in Honor of G. W. Ahlström, ed. W. Boyd Barrick, John R. Spencer, and Gösta Werner Ahlström (Sheffield: JSOT Press, 1984), 83.

38 Habel, Role, 87.

39 Habel, Role, 94.

40 Habel, Role, 94.

41 Habel, Job, 464.

42 Ash, Wisdom, 332-333.

43 Ash, Wisdom, 328; cf. 458, n.4.

44 Jean Calvin, Sermons from Job, trans. Leroy Nixon (Pelham, Alabama: Solid Ground Christian Books, 2011), 244, 246. 
Seow. ${ }^{46}$ Ash does not make the connection, but it could be argued that Elihu speaks Job's name as YHWH's spokesman, asserting authority over Job, demonstrating his own prophetic role. We noted above occasional examples elsewhere in the Old Testament of prophets calling someone directly by name, though not as often as Elihu does. The plausibility of this idea depends on the overall construal of Elihu's role as that of a genuine, inspired prophet. Even granted that, it seems an oddly excessive assertion of prophetic authority to repeat Job's name nine times, insisting on his attention.

\section{Yes, Elihu was rude!}

Elihu is portrayed as arrogant and rude, asserting an in-your-face authority over someone who is both his senior in society and suffering acutely. This understanding fits with what we have seen about marked redundancy and the use of names in the Old Testament. It also fits the context.

This impression of Elihu is not immediately clear, but it develops as his speeches continue. . The uses of Job's name in 32:12 and 33:1 could simply be clarifying participants and change of address. Elihu's initial direct address to Job in 33:1, שמע־נא איוב (hear me, please, Job), is softened by the polite particle נא. Up to this point, the reader may be in doubt. Perhaps Elihu is treating Job well. But at the end of that chapter (33:31) הקשב איוב שמע לי החרש (notice Job, listen to me, be quiet), the redundant name comes embedded in three sharp imperatives. By the time we get to Elihu's insistent demand, near the end of his fourth address: האזינה זאת איוב (pay attention to this, Job) (37:14), we have a repeated imperative to listen and a ninth use of the name. Politeness and respect have long since gone.

We noted earlier that the redundant use of Job's name is highly marked. In a direct discourse with high continuity, Runge notes that this creates "the sociolinguistic effect of push-back or countering." Moreover, "since there is no natural transition to a new topic in the speech as at 34:1, nor is Elihu countering a previous speech, the encoding creates the sense that his push-back is essentially unprovoked and hence over-the-top, regardless of whether he had used some honorific in lieu of a proper name." ${ }^{47}$ Elihu does not use an honorific and the effect is even stronger.

In our survey earlier of the use of personal names in direct address throughout the Old Testament, the overwhelming pattern was that of a superior

45 Levente Lörik, personal correspondence, e-mail to Elizabeth Robar, 13 January 2016.

46 Choon-Leong Seow, Job 1-21: Interpretation and Commentary (Grand Rapids: Eerdmans, 2013), 34-35.

47 Steven Runge, personal correspondence, e-mail to Elizabeth Robar, 12 January 2016. 
speaking to an inferior, with occasional exceptions conveying intimacy, alarm or rebuke. Revell explains, basing his remarks on the corpus of the former prophets, that for biblical Hebrew, deferential language is the norm in personal address. ${ }^{48}$ By contrast, "the names of individuals are rarely used as terms of address. Personal names were used in reference to children, and, probably, generally within the family circle." 49 However, "a human non-family member's addressing an adult by personal name alone is tantamount to treating the addressee as a child, and so is used in reference to social inferiors." ${ }^{50}$ Elihu addressed Job as if he were a child. Doing it multiple times would have been disrespectful even if he were senior to Job.

Elihu's rudeness with Job's name fits well within the Elihu section of the book. These chapters come after Job's final appeal to YHWH (chs. 29-31), before YHWH's answer and the book's conclusion (38-42). Negatively, this section shows that the three friends have been bested in discussion; they have nothing more to say. Job has declared that he has made his final appeal for God himself to intervene and will say nothing more. And during these six chapters, he, dramatically, does say nothing more, despite challenges from Elihu (33:32), and despite the pattern established earlier in the book that after a chapter or two of others' speeches, Job will have plenty to say. Also negatively, YHWH says nothing throughout these chapters. Job has made his direct appeal. The suspense builds: Will YHWH intervene? How long must we wait? Thus Elihu clearly has a dramatic role simply by not being one of the three friends, not being Job and not being YHWH. But does he have some other contribution to make?

Commentators since ancient times have wrestled with the ambiguities of Elihu. ${ }^{51}$ Longman declares he "offers nothing new to the debate." ${ }^{2}$ On the other hand, Terrien says his words "sont comparables à un vestibule qui conduit au Saint des saints. " ideas and arrogant manner. Gregory the Great wrote that, "By Elihu, who speaks indeed with a right sense, yet runs down into foolish words of pride, is

48 Ernest J. Revell, "Address, Forms of," in Encyclopedia of Hebrew Language and Linguistics, ed. Geoffrey Khan (Leiden: Brill, 2013), http://referenceworks. brillonline.com/entries/encyclopedia-of-hebrew-language-and-linguistics

$\&$ s.q $=$ address $\% 2 \mathrm{C}+$ forms + of.

49 Revell, "Address."

50 Revell, "Address."

51 Donald Carson comments: "Chapters 32-37 are among the most interesting, and the most difficult, in the book," How Long, O Lord? Reflections on Suffering and Evil, $2^{\text {nd }}$ ed. (Nottingham: Inter-Varsity Press, 2006), 148.

52 Longman, Job, 63.

53 Terrien, Job, 293. "They are like a vestibule leading to the Holy of holies." 
set forth a representation of every proud person." 54 "Even by the use of this word, 'Listen,' that he uses, he inflicts a grievous insult upon Job: it is grievous arrogance for an inferior to wish to extort for himself a hearing from his superior." 55 Chrysostom speaks of Elihu's "scornful levity." 56 Aquinas sees him, "moved not only by a zeal to defend the truth but also by vainglory." "approaches closer to the truth," the manner of contentious people." $" 59$ The Ancient Christian Commentary on Scripture summarises, "the Fathers continue to notice a certain intellectual honesty on his part that leads him to accurate assertions about the justice of God but also self-admiration and arrogance." ${ }^{60}$ Much more recently, Habel's summary is that "the poet also suggests indirectly that Elihu is a fool, albeit a brilliant young fool, but nevertheless a fool." ${ }^{, 61}$ Seow is much more positive. He is anxious that Elihu's speeches not simply be "viewed as the conceit of an arrogant young man," ${ }^{62}$ while conceding that "the poet may indeed have intended to portray Elihu as a flawed character." 63 Indeed, we can acknowledge the flawed, arrogant character without agreeing on the precise value of his ideas.

In content, Elihu's speeches are a response to Job's legal language and formal oath. ${ }^{64}$ They also pick up the theme of where wisdom can be found, from chapter $28 .{ }^{65}$ Besides content, however, in Elihu's arrogant manner, they also resonate with Job's complaint in chapters 29 and 30. Job says that before, בסוד אלוה עלי אהלי, (when God's intimate conversation was in my tent) (29:4), when he was close to me, blessings abounded (29:5-6). And the former blessings Job dwells on, much more than health and wealth, are those of social status, of being respected and looked up to (29:7-11, 21-25). In the next chapter, Job laments how things have changed and he focuses on disrespect from those who are his juniors in age and income (30:1-15). ${ }^{66}$ In the culture Job

54 Gregory the Great, cited in Johanna Manley, ed., Wisdom, Let us Attend: Job, the Fathers and the Old Testament (Menlo Park, CA: Monastery Books, 1997), 8.

55 Gregory, in Manley, Wisdom, 577.

56 John Chrysostom, cited in Manley, Wisdom, 497.

57 Aquinas, Exposition, 369.

58 Aquinas, Exposition, 365-366.

59 Aquinas, Exposition, 414.

60 Manlo Simonetti and Marco Conti, eds., Job, vol. 6 of Ancient Christian

Commentary on Scripture (Downers Grove: InterVarsity Press, 2006), 167.

61 Habel, Job, 88.

62 Seow, Job, 35.

63 Seow, Job, 97.

64 Habel, Job, 87.

65 Seow, Job, 35.

66 David J. Clines, On the Way to the Postmodern: Old Testament Essays, 19671998, 2 vols. (Sheffield: Sheffield Academic Press, 1998), 2: 800, reads this as a sign that Job himself is flawed and the narrator of the book is untrustworthy. Clines's own 
represents, status, honour and respect have high value. When, a couple of chapters later, Elihu then treats Job with disrespect, summoning him by name again and again, he is enacting precisely what Job has lamented. Job's silent endurance waiting for YHWH's intervention becomes the more impressive.

Elihu's use of Job's name was deliberately offensive. This understanding fits linguistically, it fits within broader Old Testament patterns and it fits contextually in the book. Future exegesis of the Elihu chapters of Job needs to take this aspect into account. Certainly, it qualifies positive understandings of Elihu's speeches and role.

\section{IMPLICATIONS FOR TRANSLATION}

But many readers and hearers of the Bible may never wrestle with this question, because the translation they read and the culture in which they read it combine to hide the issue. Elihu should sound rude and arrogant. If he does not, something will be missed.

This section makes translation recommendations for major languages of northern Mozambique and for some modern European languages. The recommendations can be generalised and adapted elsewhere in the world. In a language and culture where addressing someone directly by name is unusual, literally following the Hebrew and inserting Job's name in each place should be enough to call attention to what Elihu is doing. Not addressing someone by name is probably correlated to emphasising respect, using honorifics and other formulae. So Elihu's address to Job will indeed sound rude. On the other hand, in a language and culture where names are freely used in direct address, an effective translation will need to mark the use of Job's name as disrespectful.

\section{Names in northern Mozambique}

Languages of the Emakhuwa/Elomwe family (and close relatives) dominate northern Mozambique. In 2015 and 2016 I surveyed Bible and literature translation teams working in Emakhuwa ${ }^{67}$ (3.22 million speakers), Elomwe ${ }^{68}$ (1.66 million), Enahara ${ }^{69}$ (300 thousand), Emeetto ${ }^{70}$ (1.3 million), Eshirima ${ }^{71}$ (500 thousand) and Echuwabo ${ }^{72}$ (664 thousand). ${ }^{73}$ Team members are all

comments might be read as reflecting the viewpoint of an egalitarian society that does not see respect and honour as high values.

67 Juma José, Carlos Raimundo and Luís Sebastião Nenele.

68 Estevão Campama, Simões Duarte and Zacarias Pedro.

69 Saidi Chale. Ken Brown was my point of contact with the team.

70 Jacob and Amisse. Sam Pflederer was my point of contact with the team.

71 Domingos, Raimundo and Bernardo. Frits van der Merwe was my point of contact with the team.

72 João Sulude, Victor Artur Viado, Alberto Frigimo. 
mother-tongue speakers of their own language and also competent in Portuguese, Mozambique's national language. Each team was asked to give a consensus answer to a series of questions about how and when names are used in direct address in their language. (The issue of Job and Elihu was not mentioned.) The response of the Emakhuwa team was typical: "Na nossa língua os nomes não se usam, só usam com mais frequências os títulos."74 The Emeetto team backed this up with a proverb which they put into Portuguese: "Uma pessoa não se zanga na ausência." "It is not offensive to use someone's name when they are not present, ${ }^{76}$ but when they are, watch out. For Emakhuwa, titles are commonly honorific family terms like "taata" (uncle), "mulamu" (brother-in-law), "maama" (mother), "piipi" (grandfather). The team gave examples of more or less respectful pronouns, as well. The Enahara team commented that someone's own name could be used when they are considered to be a child, but once they have children of their own they are called the father or the mother of that child, such as "atuma Fin" (father of Fin). The Elomwe team gave an example of when someone's name might actually be used: "Ee, nyu João, tisheeni yeela mweenraanyu?" 77 João is clearly being rebuked. Similarly the Emeetto team gave the example: "We Manuel, waari vayi?"78 They comment that this might be a father to his son or a chief to his inferior. For Enahara, the speaker of "Whe! Bahimu, khahintu sana!"79 is plainly very angry. Another instance mentioned by the Elomwe team is when someone is calling out to someone else at a distance (perhaps across a river). The use of the name is a device for getting attention. The Elomwe, Emeetto, and Echuwabo teams also allowed that meeting a close friend after a long while apart might call for the use of the name. In Echuwabo, names can also be used in other contexts of special intimacy, but the Emeetto team specifically excluded it between husband and wife. ${ }^{80}$ For the Eshirima team, for children to even know their parents' names, much less use them, is a very recent innovation.

Across all these languages, the pattern is consistent: using a name in direct address is very unusual and implies a limited range of special

73 All these numbers but one are from M. Paul Lewis, Gary F. Simons, and Charles D. Fennig, eds., Ethnologue: Languages of the World, Nineteenth edition (Dallas, Texas: SIL International, 2016), http://www.ethnologue.com. The exception is Enahara, where the estimate is from Ken Brown, personal correspondence, e-mail to Stuart Foster, 3 June 2016.

74 "In our language you don't use names, most frequently you just use titles."

75 "A person doesn't get angry when absent."

76 The Eshirima team comment was: É normal usar o nome de alguém quando ele não estar presente. "It is normal to use someone's name when he is not present."

77 "Hey, you João, what is this that you've done?"

78 "You, Manuel, where were you?"

79 "You, Bahimu, you aren't even a person!"

80 A special case in most of these language groups would be particular relationships where rude, offensive language is expected. The Emeetto team gave several examples. 
circumstances. Any such usage is highly marked. It is not normal, proper, polite address, especially from a younger man to an older man. This pattern closely parallels that of biblical Hebrew. So, in any of these languages, Elihu's use of Job's name should be translated literally. ${ }^{81}$ It will have shock value. It will sound rude and disrespectful. It will challenge a reader to think critically about Elihu's role.

\section{Some European language translations}

That is not the case with modern, common language translations in English, Portuguese and French. A sample (GNB, ${ }^{82} \mathrm{CEVUK},{ }^{83} \mathrm{BPT},{ }^{84} \mathrm{FCL}^{85}$ ) shows that they tend to use Job's name just where the original does. ${ }^{86}$ And, of course, more word-for-word translations do the same (NIV84, ${ }^{87} \mathrm{NRS} 89,{ }^{88}$ REB89, ${ }^{89}$ $\left.\mathrm{RC} 295,{ }^{90} \mathrm{NBS} 02^{91}\right)$. But in these languages, using someone's name directly is common. It is more likely to sound warm and friendly than it is rude and offensive. So in the Good News Bible, Elihu's shocking, climactic use of Job's name becomes the gentle:

"Pause a moment, Job, and listen;

Consider the wonderful things God does." (37:14)

Such translations fail their readers. They hide important clues about the role of Elihu. Instead, translations with a more formal, word-for-word, approach should use notes to draw the reader's attention to Elihu's consistently offensive style. A common language translation in English should say something like: "Hey, you! Job! Listen up," in 33:1, 31 and 37:14. Getting just the right level of rudeness for each audience is, of course, difficult, because it depends profoundly on cultural assumptions. Where brash young men are applauded, it will always be hard to see Elihu critically. But Bible translations can do better, much better.

81 A vocative might also be added.

82 Good News Bible (New York: American Bible Society, 1976).

83 Contemporary English Version (Reading: British and Foreign Bible Society, 1997).

84 A Bíblia Para Todos (Lisbon: Sociedade Bíblica de Portugal, 2009).

85 La Bible en Français Courant (Paris: Alliance Biblique Française, 1997).

86 The CEVUK adds an instance in 34:6. It moves the usage in 34:35 to $34: 34$ and drops the name in $34: 36$. The GNB moves the name in $35: 16$ to $35: 14$. This is less exact than BPT and FCL, but quite close.

${ }^{87}$ New International Version (Colorado Springs: International Bible Society, 1984).

88 New Revised Standard Version (Oxford: Oxford University Press, 1989).

89 Revised English Bible (Cambridge: Cambridge University Press, 1989).

90 Bíblia Sagrada Almeida Revista e Corrigida (São Paulo: Sociedade Bíblica do Brasil, 1995).

91 La Nouvelle Bible Segond (Paris: Alliance Biblique Française, 2002). 


\section{E CONCLUSION}

Elihu's use of Job's name, over and over again, is both striking and significant when set in its larger contexts. Understanding it is essential to understanding Elihu's role in the book of Job. For too long, this detail has been neglected by commentators and obscured by translators. But a perspective from northern Mozambique can help it be heard, and communicated.

\section{BIBLIOGRAPHY}

Aquinas, Thomas. The Literal Exposition on Job: A Scriptural Commentary Concerning Providence. Translated by Anthony Danico. Atlanta, Georgia: Scholars Press, 1989.

Ash, Christopher. Job: The Wisdom of the Cross. Wheaton, Ill: Crossway, 2014.

Calvin, Jean. Sermons from Job. Translated by Leroy Nixon. Pelham, Alabama: Solid Ground Christian Books, 2011.

Carson, Donald A. How Long, O Lord? Reflections on Suffering and Evil. $2^{\text {nd }}$ ed. Nottingham: Inter-Varsity Press, 2006.

Cheney, Michael. Dust, Wind and Agony: Character, Speech and Genre in Job. Stockholm: Almqvist \& Wiksell, 1994.

Clines, David J. A. On the Way to the Postmodern: Old Testament Essays, 1967-1998. 2 Vols. JSOTSuppl 292 and 293. Sheffield: Sheffield Academic Press. 1998. . Word Biblical Commentary, Volume 18A, Job 21-37. Nashville:

Tyndale House, 2006.

Dhorme, Édouard Paul. A Commentary on the Book of Job. Translated by Harold Knight. London: Thomas Nelson, 1967.

Gordis, Robert. The Book of Job: Commentary, New Translation and Special Studies. New York City: The Jewish Theological Seminary, 1978.

Habel, Norman. C. "The Role of Elihu in the Design of the Book of Job." Pages 81-98 in In the Shelter of Elyon: Essays of Ancient Palestinian Life and Literature in Honor of G. W. Ahlström. Edited by W. Boyd Barrick, John R. Spencer, and Gösta Werner Ahlström. JSOTSup 31. Sheffield: JSOT Press, 1984. . The Book of Job: A Commentary. London: SCM Press, 1985.

Hakkam, Amos. The Bible: Job with the Jerusalem Commentary. Jerusalem: Mosad Harav Kook. 2009.

Janzen, J. Gerald. Job. Interpretation: A Bible Commentary for Teaching and Preaching. Atlanta: John Knox Press, 1985.

Lewis, M. Paul, Gary F. Simons, and Charles D. Fennig, eds. Ethnologue: Languages of the World, Nineteenth edition. Dallas, Texas: SIL International, 2016. http://www.ethnologue.com.

Longman III, Tremper. Job. Grand Rapids: Baker Academic, 2012. 
Manley, Johanna, ed. Wisdom, Let us Attend: Job, the Fathers and the Old Testament. Menlo Park, CA: Monastery Books, 1997.

Nicole, Jules M. Le Livre de Job. Vol. 2. Vaux sur Seine: Edifac, 1987.

Pope, Marvin R. The Anchor Bible: Job. Introduction, Translation and Notes. Garden City, New York: Doubleday, 1973.

Revell, Erenst J. "Address, Forms of." Encyclopedia of Hebrew Language and Linguistics. Edited by Geoffrey Khan. Leiden: Brill, 2013. http://referenceworks.brillonline.com/entries/encyclopedia-of-hebrewlanguage-and-linguistics \&s.q=address $\% 2 \mathrm{C}+$ forms + of.

Reyburn, William D. A Handbook on the Book of Job. New York: United Bible Societies, 1992.

Rowley, Harold H. New Century Bible: Job. London: Marshall, Morgan \& Scott, 1976.

Runge, Steven E. "Pragmatic Effects of Semantically Redundant Anchoring Expressions in Biblical Hebrew Narrative." Journal of Northwest Semitic Languages 32 (2006): 87-104. ."Redundancy, Discontinuity and Delimitation in the Epistle of James." Paper presented in the "Hellenistic Greek Language and Literature" Section of the SBL International Meeting, London, UK, July 3-7, 2011.

Seow, Choon-Leong. Job 1-21: Interpretation and Commentary. Grand Rapids: Eerdmans, 2013.

Simonetti, Manlo and Marco Conti, eds. Job, vol. 6 of Ancient Christian Commentary on Scripture. Downers Grove: InterVarsity Press, 2006.

Terrien, Samuel. Job. $2^{\text {nd }}$ ed. Geneva: Labor et Fides, 2005.

Wharton, James A. Job. Louisville, Ky: Westminster John Knox Press, 1999.

Wilson, Gerald H. New International Biblical Commentary: Job. Peabody, Mass.: Hendrickson, 2007.

Dr. Stuart Foster, Research associate, University of Stellenbosch. SIM Mozambique, Gurué, Zambézia, Mozambique.Email: stuart.foster@sim.org. 